\title{
To exclude or not to exclude, that is the question. Developments regarding bases for exclusion from refugee status in the EU
}

\author{
Janja Simentić*
}

(Received 22 August 2017; accepted 18 January 2018)

\begin{abstract}
In this Article, the author presents and explains the current normative framework in EU law about the exclusion from refugee status based on the premise that a person is not deserving of refugee status. This article is directed at clarifying the present content of the legislation in force and the caselaw of the Court of Justice of the European Union that further elaborates on this issue. The Commission's recent proposal for new legislation is also scrutinized, in order to present a possible evolution of the exclusion provision.
\end{abstract}

Keywords: refugee status; qualification directive; non-refoulement

\section{A. Introduction}

This article aims to present and explain the current normative framework in EU law that deals with the bases for exclusion from refugee status. The norms concerning the exclusion from refugee status are found in the Qualification Directive (QD) ${ }^{1}$ and are further elaborated on in the caselaw of the Court of Justice of the European Union. This article will deal only with the exclusion from refugee status founded on the premise that the individual in question is not deserving of that protection. $^{2}$ The exclusion because the individual is already in receipt of some form of protection ${ }^{3}$ is beyond the scope of this article.

In international law, the bases for exclusion from refugee status are contained in Article 1 (F) of the 1951 Convention relating to the Status of Refugees (Refugee Convention, Geneva Convention). The Qualification Directive incorporates this rule into Article 12(2), which "corresponds in

\footnotetext{
${ }^{*} J a n j a$ Simentić is a Teaching Assistant and PhD student at the University of Belgrade, Faculty of Political Science. Email: janja. simentic@fpn.bg.ac.rs.

${ }^{1}$ See Council Directive 2004/83/EC of April 29, 2004 On Minimum Standards for the Qualification and Status of Third Country Nationals or Stateless Persons as Refugees or as Persons Who Otherwise Need International Protection and the Content of the Protection Granted, 2004 O.J. (L 304) 12 (EC) [hereinafter Former Qualification Directive]; see also Directive 2011/95/EU of the European Parliament and of the Council of 13 December 2011 On Standards for the Qualification of Third-Country Nationals or Stateless Persons as Beneficiaries of International Protection, for a Uniform Status for Refugees or for Persons Eligible for Subsidiary Protection, and for the Content of the Protection Granted (Recast), 2011 O.J. (L 337) 9 (EU) [hereinafter Qualification Directive].

${ }^{2}$ See Convention Relating to the Status of Refugees art. 1(F), Jul. 28, 1951, 189 U.N.T.S. 137 [hereinafter Refugee Convention], https://reaties.un.org/doc/Treaties/1954/04/19540422\%2000-23\%20AM/Ch_V_2p.pdf; see also Qualification Directive, supra note 1, art. 12(2).

${ }^{3}$ See Refugee Convention, supra note 2, arts. 1(D), (E); see also Qualification Directive, supra note 1, art. 12(1).
} 
substance to ... Article 1F of the 1951 Refugee Convention." ${ }^{4}$ Therefore, this provision will be the main subject of analysis of this article. It is often overlooked, however, that the QD potentially contains an additional basis for exclusion from refugee status in Article 14(5). It seems that this Article in fact introduces an exception to the non-refoulement rule as a basis for exclusion from refugee status. Keeping in mind that this solution is made more explicit in the current Commission's proposal for the new Qualification Regulation, ${ }^{5}$ it is important to understand the implications of this provision for refugee protection in the Union. Therefore, the main objective of this article will be achieved in the following manner. First, a brief overview of the basis for exclusion in international law will be provided in order to get acquainted with the genesis of the exclusion clause in the Refugee Convention. Then, the rules now in force in the EU on the exclusion from refugee status will be presented and analyzed. Next, the relevant caselaw of the Court of Justice of the European Union (CJEU) will be taken into consideration in order to fully grasp the exclusion regime in the EU. Finally, a new Commission proposal will be scrutinized, taking into special consideration its aim to add clarifications on the grounds for exclusion based on CJEU caselaw, as well as its emphasis on the basis for exclusion that goes beyond the framework adopted in the 1951 Refugee Convention.

\section{B. Exclusion from Refugee Status in International Law}

The first international instruments after the Second World War that contained provisions concerning the exclusion from refugee protection or asylum were the Constitution of International Refugee Organization in 1946 and the Universal Declaration of Human Rights (UDHR) in 1948. Among the prevalent organizational provisions of the Constitution of International Refugee Organization was Part II of Annex II, which contained an enumeration of persons that would not receive assistance from that Organization. Also, Article 14(2) of the UDHR stated that persons who committed non-political crimes or acts contrary to the purposes and principles of the United Nations could not invoke the right to asylum. These documents, however, had intrinsic legal limitations. The first document, on the one hand, was a constitution of an international organization that was formed with a concrete task - to respond to the atrocities of the Second World War and the consequences it produced for refugees and internally displaced persons. Therefore, it covered precisely defined categories of people with a clear reference to Second World War. Universal Declaration, on the other hand, was striving to promote universal human rights but was not a legally binding document. Also, regarding the right to asylum, it did not contain the right to be granted asylum or, as a matter of fact, the explanation of this notion.

When the Office of the United Nations High Commissioner for Refugees (UNHCR) finally took over the work of International Refugee Organization in 1952, its Statute did not contain an exclusion clause. It relied upon a newly adopted-but not yet in force-Convention on Refugees, however. The Convention on the Status of Refugees contained both the general definition of the refugee and situations in which the Convention will not be applied to a person, creating the basis for exclusion from refugee status. ${ }^{6}$ This Article is still in force and defines the exclusion from refugee status in the following manner:

${ }_{4}^{4}$ Joined Cases C-57/09 \& C-101/09, Bundesrepublik Deutschland v. B \& D, 2010 E.C.R. I-10979, para. 72, [hereinafter B and D, Cases C-57/09 and C-101/09], https://eur-lex.europa.eu/legal-content/EN/TXT/?uri=CELEX\%3A62009CJ0057.

${ }^{5}$ Proposal for a Regulation of the European Parliament and of the Council on Standards for the Qualification of ThirdCountry Nationals or Stateless Persons as Beneficiaries of International Protection, for a Uniform Status for Refugees or for Persons Eligible for Subsidiary Protection and for the Content of the Protection Granted and Amending Council Directive 2003/109/EC of November 25, 2003 Concerning the Status of Third-Country Nationals Who are Long-Term Residents, COM (2016) 466 final (Jul. 13, 2016) [hereinafter Proposal for Qualification Directive] https://publications.europa.eu/en/ publication-detail/-/publication/6d976705-4a95-11e6-9c64-01aa75ed71a1.

${ }^{6}$ See Refugee Convention, supra note 2, art. 1(F). The Refugee Convention was also drafted in order to deal with the displacement of people as a result of Second World War. It did not contain the express reference to this purpose, however, apart from the geographical and temporal limitation that were later repealed by the adoption of 1976 Protocol. 
The provisions of this Convention shall not apply to any person with respect to whom there are serious reasons for considering that: (a) He has committed a crime against peace, a war crime, or a crime against humanity, as defined in the international instruments drawn up to make provision in respect of such crimes; (b) He has committed a serious non-political crime outside the country of refuge prior to his admission to that country as a refugee; (c) He has been guilty of acts contrary to the purposes and principles of the United Nations.

Several explanations can be found in literature about the reasons for the introduction of the exclusion clause, ranging from "promotion of an international morality through refugee law" ${ }^{7}$ to states' practical concern of avoiding conflicts between their duty to protect refugees and their obligations under extradition treaties.

In practice, several issues have emerged as possible obstacles to uniform application of this provision. Regarding the grounds for exclusion, the least controversial basis is Article 1(F)(a). The notions used in this Article are relatively straightforward, especially keeping in mind the evolution that both international humanitarian law and criminal law underwent throughout the years. Article $1(\mathrm{~F})(\mathrm{b})$ - and its use of the notion of a "non-political act"-is highly controversial, however, because it heats up the disagreements about the very raison d'être of this whole provision. Namely, it is used as an indicator for those authors that claim that the reason for the adoption of the exclusion clause was to balance the obligations of states regarding extradition and obligation to provide protection. Also, the very notions of serious and non-political acts are open-ended and susceptible to different interpretations. Another issue that emerges is whether proportionality should be taken into account when balancing the acts committed and the need for protection. Article $1(\mathrm{~F})(\mathrm{c})$ is problematic because it ties the obligations of states-to respect the purposes and principles of the United Nations - with the behavior of the individuals. It is left open whether that individual has to be in a position of power in order to be able to commit such acts. Also, it is left open what types of behavior can be labeled as contrary to the purposes and principles of the United Nations. Because an international refugee court does not exist, these questions were tackled by different national courts, and vast jurisprudence emerged. ${ }^{8}$

By incorporating practically the same provision in its body of law, EU law shares the same problems and obstacles in its application. Also, the EU judicial system-with CJEU on the forefront-offered some solutions for these problems. EU law, however, represents a fertile ground for further uncertainties about this concept. First, EU law possibly contains an additional ground for exclusion, apart from those enumerated in the Geneva Convention. Second, the new Commission proposal offers some new developments in the field that are relevant and alarming. In order to better understand the state of affairs in the EU regarding the exclusion clause, we will continue to point to these issues-as well as to CJEU caselaw-for further guidance.

\section{Exclusion from Refugee Status in EU Law-Analysis of the Legislation in Force}

After the Tampere Program in 1999 and the goal set therein-namely, to create a Common European Asylum System (CEAS) — the Commission embarked on the task to propose several legal acts in this field. One such act was Qualification Directive (QD) that aimed "to guide the competent authorities of the Member States in the application of. .. [Refugee Convention] on the basis of common concepts and criteria." 9 Therefore, it was clear from the outset that the

\footnotetext{
${ }^{7}$ James C. Hathaway \& Colin J. Harvey, Framing Refugee Protection in the New World Disorder, 34 CORNELL INT'L L.J. 257, 263 (2001).

${ }^{8}$ See Gina Clayton, Immigration and Asylum Law 510-22 (5th ed. 2012) (discussing relevant case law).

${ }^{9}$ Case C573/14, Commissaire Général aux Réfugiés et aux Apatrides v. Lounani, para. 41 (Jan. 31, 2017) [hereinafter Lounani], http://curia.europa.eu/juris/liste.jsf?num=C-573/14.
} 
QD was intended to be used as a means to reduce disparities between the legislation of Member States and the in-field practice of recognition of refugee status and its content. Additionally, the QD was intended to establish a minimum level of protection in all Member States, but based on provisions of Geneva Convention. ${ }^{10}$ Having that goal in mind, the Commission transposed the refugee definition from the Geneva Convention in its first proposal for the QD. Also, the bases for exclusion from refugee status were the same as those in the Geneva Convention. In the part of its explanatory memorandum titled Applicants Not Deserving of International Protection, the Commission presented and provided an explanation for every basis for exclusion from refugee status. The Commission's proposal also included: Procedural safeguards for persons excluded from refugee status - such as the right to proceedings before a court against a decision to exclude them from refugee status; a high standard of proof ${ }^{11}$; and the explanation that the application of exclusion shall not in any manner affect the obligations that Member States have under international law. ${ }^{12}$ Also, nowhere in the Commission's proposal was a provision about revoking, ending, or refusing to renew refugee status. The Council, however, adopted a changed version of the Directive. ${ }^{13}$

First, the adopted Directive included a slightly changed wording of Article 12 which contains the bases for exclusion. ${ }^{14}$ In part 2(b), it included an explanation that admission as a refugee meant "the time of issuing a residence permit based on granting of refugee status." 15 It also added that "particularly cruel actions, even if committed with an allegedly political objective, may be classified as serious non-political crimes." ${ }^{\prime 6}$ From the outset, this provision attracted negative reactions because of the definition of the notion admission as refugee. The UNHCR pointed out that by including this definition, Article 12(2)(b) becomes inconsistent with Article 1F of the Geneva Convention because it defies its geographical and temporal limitation. Namely-according to the Geneva Convention-relevant crimes need to be committed outside the country of refuge and prior to the admission therein as a refugee. ${ }^{17}$ The UNHCR insisted that refugee status is declaratory and not constitutive, and that therefore admission must include merely physical presence in the country of refuge. It also seems that this definition could contradict its own wording. It claims that a serious non-political crime should be committed outside of the country of refuge. In practice, however, it is possible to imagine an asylum seeker committing a crime within the country of refuge, but prior to issuing a residence permit. In that situation, it remains to be seen which criteria will prevail; will this act be excluded based on geographical place of the committed act or included based on the procedural aspect of issuing a residence permit? This Article could become contradictory, and it remains to be seen how this situation will be solved in practice. ${ }^{18}$

Coming back to the substance of the first QD, it is important to point out that the final version of the QD does not contain the safeguards that the Commission proposed. Instead, it includes the

\footnotetext{
${ }^{10}$ See Proposal for a Council Directive on Minimum Standards for the Qualification and Status of Third Country Nationals and Stateless Persons as Refugees or as Persons Who Otherwise Need International Protection, COM (2001) 510 final (Oct. 30 , 2001) [hereinafter Minimum Standards Proposal] (setting a relevant scope for this issue).

${ }^{11}$ Grounds for exclusion shall be based solely on the personal and knowing conduct of the person concerned.

${ }^{12}$ See Minimum Standards Proposal, supra note 10, art. 14.

${ }^{13}$ See Elspeth Guild \& Madeline Garlick, Refugee Protection, Counter-Terrorism, and Exclusion in the European Union, 29 Refugee SuRv. Q. 63, 74-75 (2011) (describing the general political climate in the time of adopting QD).

${ }^{14}$ Former Qualification Directive, supra note 1, art. 12.

${ }^{15}$ Qualification Directive, supra note 1, art. 12(2)(b).

${ }^{16} I d$.

${ }^{17}$ U.N. High Comm'r for Refugees, Annotated Comments on the EC Council Directive 2004/83/EC of April 29, 2004 on Minimum Standards for the Qualification and Status of Third Country Nationals or Stateless Persons as Refugees or as Persons Who Otherwise Need International Protection and the Content of the Protection Granted (OJ L 304/12 of 30.9.2004), 27 (Jan. 2005) [hereinafter Annotated Comments], https://www.unhcr.org/en-us/protection/operations/43661eee2/unhcrannotated-comments-ec-council-directive-200483ec-29-april-2004-minimum.html.

${ }^{18}$ See Francesco Cherubini, Asylum Law in the European Union 214-15 (2015).
} 
provision that "persons who instigate or otherwise participate in the commission of the crimes or acts mentioned therein" are also excluded from refugee status. ${ }^{19}$

The most worrying aspect of the final Qualification Directive, however, is the inclusion of Article 14(5), which contains the grounds for revoking, ending, or refusing to renew refugee status. Part 4 states that Member State may revoke, end, or refuse to renew the status granted to refugee if: a) There are reasonable grounds for regarding the person as a danger to the security of the Member State in which he or she is present; or b) the person-having been convicted by a final judgment of a particularly serious crime-constitutes a danger to the community of that Member State. It is also stated that in cases where decision on refugee status has not yet been taken, these reasons can be used as grounds not to grant it. ${ }^{20}$ Some authors claim that the inclusion of this provision effectively presents an additional ground for exclusion from refugee status not provided in the Refugee Convention. ${ }^{21}$ It needs to be pointed out, however, that the provision is formulated in such manner that leaves discretion to the state as to whether to use that provision as the basis for deciding not to grant status to refugees-by using the term may instead of shall.

The meaning of the notion "not to grant status to refugees" is key to understanding whether this provision represents a ground for exclusion. Until its meaning is fully understood and determined, it continues to present a weak link in the refugee protection mechanism of the Union. Currently, there are two cases pending before the CJEU in which the Belgium court asked Court of Justice "[m] ust Article 14(5) of Directive 2011/95/EU be interpreted as creating a new ground for exclusion from refugee status provided for in Article 13 of the Directive and, consequently, from Article 1A of the Geneva Convention?"22 Until the judgments are given, this question remains open and susceptible to theoretical analysis.

There are two ways to interpret this provision. The first interpretation-advocated by UNHCR-is that the:

"status granted to a refugee" is understood. .. to refer to the asylum ("status") granted by the State rather than refugee status in the sense of Article 1 A (2) of the 1951 Convention. States are ... obliged to grant the rights of the 1951 Convention which do not require lawful residence and which do not foresee exceptions for as long as the refugee remains within the jurisdiction of the State concerned. ${ }^{23}$

If this interpretation is accepted, then there are no uncertainties about the possible introduction of the new basis for exclusion from refugee status. Moreover, this view would support and embody the declaratory approach to the nature of refugee status. Namely, it is often claimed that refugee status is only declaratory and not constitutive. This practically means that as soon as the conditions for the refugee definition are fulfilled, the person becomes a refugee-with or without formal recognition. ${ }^{24}$ Therefore, refugee status is a matter of fact, not a matter of law. ${ }^{25}$ Even the QD in its recital 14 adopts this view. ${ }^{26}$ When it comes to practical application of this stance, however, some difficulties arise. Namely, as UNHCR points out, "[t]he authority called upon to apply or

\footnotetext{
${ }^{19}$ Qualification Directive, supra note 1, art. 12(3).

${ }^{20}$ Qualification Direction, supra note 1, at art. 14(5).

${ }^{21}$ See Guild \& Garlick, supra note 13, at 73; see also CHERUBINI, supra note 18, at 217; Ben Saul, Exclusion of Suspected Terrorists from Asylum: Trends in International and European Refugee Law, IIIS Discussion PAPER No. 26, at 5 (2004).

${ }^{22}$ See Case C-77/17, Walkner v. Aviation Passage Service Berlin GmbH \& Co. KG, http://curia.europa.eu/juris/liste.jsf? language=en\&td=ALL\&num=C-77/17; see also Case C-78/17, X v. Commissaire Général aux Réfugiés et aux Apatrides, http://curia.europa.eu/juris/liste.jsf?language=en\&td=ALL\&num=C-78/17.

${ }^{23}$ Annotated Comments, supra note 17 , at 31.

${ }^{24}$ See U.N. High Comm'r for Refugees, Note on Determination of Refugee Status Under International Instruments, para. 5, EC/SCP/5 (Aug. 24, 1977) [hereinafter UNHCR Note on Determination].

${ }^{25}$ Hemme Battjes, European Asylum Law and International Law 456 (2006).

${ }^{26}$ See Former Qualification Directive, supra note 1, at recital 14 (“The recognition of refugee status is a declaratory act.").
} 
implement a legal instrument relating to refugees cannot do so unless the refugees are identified as such. Whilst the instrument may not provide expressly for determination of refugee status, such a determination is nevertheless an inherent requirement." ${ }^{27}$ It is obvious that the formal recognition is needed in order to apply the relevant legal framework to that person and ensure protection. Therefore, it seems that the statement that determination of refugee status is of declaratory nature is itself only declaratory, and does not provide any useful help in the assurance that the standards of protection are respected. The problem with viewing refugee status as a matter of fact is that there is always a need for somebody to determine or establish that fact.

It also seems that the EU's acceptance of the declaratory approach is unsubstantiated. An indicator that EU law actually supports the constitutivist view on refugee status determination is the existence of Reception Condition Directive. This Directive provides for different legal regimes to be applied to the applicants of asylum before they become recognized refugees. ${ }^{28}$ Additionally, Battjes promotes the view that even the Geneva Convention contains both declaratory and constitutive approaches to refugee status - namely, that some provisions embody the first approach and others the second. ${ }^{29}$ Nonetheless, if we accept that refugee status recognition is constitutive to refugee status determination, then the notion not to grant status to refugee means that the person will be deprived of refugee status and therefore of its protection. Under this approach, Article 14(5) effectively becomes an additional basis for exclusion from refugee status that does not exist in the Geneva Convention.

Even though this basis for exclusion from refugee status does not exist in the Refugee Convention, the wording of this Article can be found in the Convention-albeit as a different rule-under the exception to non-refoulement. Namely, Article 33(2) of the Geneva Convention contains the exception to the non-refoulement principle, stating that

the benefit of the present provision may not, however, be claimed by a refugee whom there are reasonable grounds for regarding as a danger to the security of the country in which he is, or who, having been convicted by a final judgment of a particularly serious crime, constitutes a danger to the community of that country.

It is clear from the wording of Article 33, however, that it is intended to apply to persons who already have refugee status but are considered a danger to the security or community of the country in which they find themselves. This provision is not intended to be used as preventive mechanism-that would from the outset exclude a person from obtaining refugee status. Instead, it is to be used as a corrective mechanism that would enable states to protect their security and community once a person is recognized as a refugee and residing in their country. The exclusion criteria were based on the presumption that not everybody deserves international protection, while the exception to non-refoulement presents a balance reached between the obligation to protect persons in need and to protect the safety of a country. Therefore, the exclusion criteria are to be applied before or at the same time as the procedure for recognition of refugee status is triggered, ${ }^{30}$ while the non-refoulement exception comes in only when the already recognized refugee becomes involved in activities dangerous for the present country. Thus, the standard

\footnotetext{
${ }^{27}$ Note on Determination, supra note 24 , at para. 4 (citation omitted).

${ }^{28}$ See Battjes, supra note 25, at 455.

${ }^{29}$ Id. at 463

It appears, that Article 32 applies only to recognised refugees, and Article 33 to unrecognised refugees as well.

Hence, we cannot decide that status determination is in general declaratory or constitutivist in nature. Rather, we will have to sort out for each Convention benefit separately which of the two views applies.

${ }^{30}$ See Geoff Gilbert, Current Issues in the Application of the Exclusion Clauses, in REFUGEE PROTECTION IN INTERNATIONAL LAW 464-66 (Erika Feller et al. eds., 2003) (demonstrating a difference in practice); see also David Kosar, Inclusion Before Exclusion or Vice Versa: What the Qualification Directive and the Court of Justice Do (Not) Say, 25 Int'l J. ReFUGEE L. 87 (2013) (debating the "exclusion before inclusion" or vice versa); CLAYTON, supra note 8, at 511-12 (explaining the practice in the UK).
} 
of proof in these two situations is not the same. In the case of exclusion, the standard is "serious reasons for considering that," while the non-refoulement exception standard is "reasonable grounds" or "conviction by a final judgement." 1

The exception to the non-refoulement rule is frequently mixed and interchanged, especially with the grounds from exclusion in Article 12(2)(b) QD. This can be seen from the $B$ and $D$ case before the CJEU, where the national court asked whether the exclusion from refugee status pursuant to Article 12(2)(b) or (c) of Directive 2004/83 is conditional upon the concerned person's continued representation of danger to the host Member State. ${ }^{32}$ The CJEU answered in the negative, stating that such a condition is not consistent with the objectives of the exclusion clauses, such as to exclude undeserving persons, to prevent the avoidance of criminal liability, and to make exclusion "conditional upon the existence of a present danger to the host Member State." 33 This is an interesting observation of the Court-keeping in mind that it failed to mention Article 14(5) of the QD, which makes that exact observation.

It is sometimes said that the difference between these two provisions-Article 1(F) Refugee Convention/12(2)(b) QD for crimes committed before entrance to the country of refuge and Article 33(2) Refugee Convention/ Article 21(2) QD for crimes committed after admission as a refugee ${ }^{34}$-rests on the time frame of the commission of the alleged acts. That it is a misleading position, however. The time of the occurrence of the criminal act is not the true cause of distinction between these two regimes-it is a consequence of such distinction. Namely, the true cause for distinction is the difference in aims of the two provisions. The first one has a moral background; it seeks to exclude those persons who are undeserving of refugee protection. The second one has a security background; it seeks to include considerations about the security of a receiving state.

It is also important to note that neither of these two provisions-Article $1(\mathrm{~F})$ and Article 33(2) of the Refugee Convention-deal with the withdrawal of refugee status. Under the first provision, refugee status cannot be granted at all. Under the second provision, it is not about the withdrawal of the refugee status, but rather about the decision to expel a person from a state. Even in that case, however, the person still keeps refugee status-it is not taken away. ${ }^{35}$ Moreover, it is interesting to note that the Refugee Convention does not contain any reference to the withdrawal of refugee status. The UNHCR provides three ways to terminate refugee protection for different reasons ${ }^{36}$ - and only one deals with the revocation of refugee status if persons engage in conduct that is prohibited by Article $1(\mathrm{~F})(\mathrm{a})$ and $(\mathrm{c})$. It is interesting to note that this possibility emerges only in the UNHCR - the Refugee Convention itself did not contain such provision. This new tendency, and its frequent use in practice, clearly marks the shift from the approach in the Geneva Convention-where refugees were regarded as vulnerable categories of persons in need of international protection - to the approach based on labeling refugees as dangerous individuals. This trend is obviously even more emphasized in EU law, keeping in mind the abovementioned provisions for the revocation of refugee status.

\footnotetext{
${ }^{31}$ Hathaway \& Harvey, supra note 7, at 260 (pointing out that by relying on bases from Article 33(2) while applying the less strict procedure for exclusion from Article $1(\mathrm{~F})$, the states get "best of both worlds").

${ }^{32}$ See $B$ and D, Cases C-57/09 and C-101/09 at para. 100.

${ }^{33} I d$. at para. 104.

${ }^{34}$ Saul, supra note 21 , at 5 .

${ }^{35}$ Guy S. Goodwin-Gill \& Jane Mcadam, The Refugee in International Law 244 (3rd ed. 2007).

${ }^{36}$ Annotated Comments, supra note 17 , at 28

Cessation refers to the ending of refugee status pursuant to Article 1C of the 1951 Convention because international refugee protection is no longer necessary or justified. Cancellation means a decision to invalidate a refugee status recognition, which is appropriate where it is subsequently established that the individual should never have been recognized, including in cases where he or she should have been excluded from international refugee protection. Revocation refers to the withdrawal of refugee status in situations where a person properly determined to be a refugee engages in conduct which comes within the scope of Article $1 \mathrm{~F}(\mathrm{a})$ or (c) of the 1951 Convention after recognition.
} 
While there are those who still advocate that the exclusion from refugee status and the exception to the non-refoulement rule are not to be placed in the same basket, ${ }^{37}$ practice defies these calls. ${ }^{38}$ Until the CJEU directly solves this issue through its currently pending cases, the debate will continue. Thus, it remains to be seen what is the current contribution of the CJEU to the understanding of the exclusion clause in EU law. Therefore, the next part of this Article will present developments in CJEU case law that are relevant for the interpretation of the exclusion clause in EU law.

\section{Exclusion from Refugee Status in EU Law in Practice: Case Law of the CJEU}

Article 12(2)(b) of the QD-reflecting Article 1(F)(b) of the Geneva Convention-contains notions of serious and non-political crimes that are susceptible to conflicting interpretations. The CJEU had the opportunity to shed light on these notions in its ruling in $B$ and $D$ case. In this case, $\mathrm{B}-\mathrm{a}$ Turkish national and supporter of DevSol (DHKP/C) - asked for asylum in Germany. He was rejected because he committed a serious non-political crime. D-also a Turkish national-is a member of the PKK who obtained asylum in Germany. The authorities later wanted to revoke his asylum, however, because he committed a serious non-political crime outside of Germany before being admitted to its territory as a refugee, and was also found guilty of acts contrary to the purposes and principles of the United Nations. The CJEU decided to join the two cases and deliver one judgment on this matter.

As for the definition of the non-political character of the crime, the Court of Justice stated that "it is clear that terrorist acts, which are characterized by their violence towards civilian populations, even if committed with a purportedly political objective, fall to be regarded as serious non-political crimes within the meaning of point (b)." ${ }^{9} 9$ This stance is in line with the UNHCR's interpretation of this notion. The UNHCR explains that terrorist acts will usually be included in the category of non-political acts because in most cases they are disproportionate to any political objective and therefore considered as non-political acts. ${ }^{40}$ As Clayton puts it, "[a] serious political crime may be so either because it never had any political connection or motivation, or because the consequences of it are so severe that it can no longer be treated as political." 41

Another issue that emerges in dealing with this question is whether proportionality should be taken into account when balancing the acts committed with the need for protection. The Court of Justice pointed out that:

Exclusion from refugee status on one of the grounds laid down in Article 12(2)(b) or (c) of Directive 2004/83 ... is linked to the seriousness of the acts committed, which must be of such a degree that the person concerned cannot legitimately claim the protection attaching to refugee status under Article 2(d) of that directive. ${ }^{42}$

\footnotetext{
${ }^{37}$ See U.N. High Comm'r for Refugees, Guidelines on International Protection: Application of the Exclusion Clauses: Article 1F of the 1951 Convention Relating to the Status of Refugees, para. 4, HCR/GIP/03/05 (Sept. 4, 2003) [hereinafter UNHCR Guidelines on International Protection], https://www.unhcr.org/en-us/publications/legal/3f7d48514/guidelines-internationalprotection-5-application-exclusion-clauses-article.html; see also Hélène Lambert, The EU Asylum Qualification Directive, Its Impact on the Jurisprudence of the United Kingdom and International Law, 55 INT'l \& CoMP. L.Q. 161, 178 (2006).

${ }^{38}$ See United Kingdom: Home Office, Exclusion (Article 1F) And Article 33(2) of the Refugee Convention (Jul. 5, 2016), https://assets.publishing.service.gov.uk/government/uploads/system/uploads/attachment_data/file/534985/exclusion_ and_article_33_2_refugee_convention.pdf.

${ }^{39} \mathrm{~B}$ and $\mathrm{D}$, Cases C-57/09 and C-101/09 at para. 81.

${ }^{40}$ U.N. High Comm'r for Refugees, Statement on Article 1F of the 1951 Convention Issued in the Context of the Preliminary Ruling References to the Court of Justice of the European Communities from the German Federal Administrative Court Regarding the Interpretation of Articles 12(2)(b) and (c) of the Qualification Directive, at 12 (2009) [hereinafter UNHCR Statement on Article 1F], https://www.unhcr.org/en-us/4a5edac09.pdf.

${ }^{41}$ ClaytON, supra note 8 , at 515-18, (featuring case law regarding this notion).

${ }^{42} B$ and $D$, Cases C-57/09 and C-101/09 at para. 108.
} 
The Court was of the stance that national authority already included all the important circumstances in the assessment of the seriousness of the committed acts and the person's individual responsibility. Therefore, the Court believes there is no need for an additional assessment of these facts. ${ }^{43}$ While it is true that acts contrary to the purposes and principles of the United Nations are per se serious acts, the question remains whether every act that could be included in Article 12(2)(b) fulfils the condition of seriousness. The UNHCR is of stance that proportionality considerations are a necessary safeguard for human rights protection and are in line with the humanitarian object and purpose of the Geneva Convention. According to the UNHCR, the gravity of the offence in question is weighed against the consequences of exclusion. ${ }^{44}$ The UNHCR, however, differentiates between crimes against peace, crimes against humanity, and acts falling under Article $1 \mathrm{~F}(\mathrm{c})$ on the one hand, and Article $1 \mathrm{~F}(\mathrm{~b})$ crimes and less serious war crimes under Article $1 \mathrm{~F}(\mathrm{a})$, on the other hand. The former are considered so heinous that proportionality considerations are usually not needed, while the latter require these considerations. ${ }^{45}$ The ruling of the $\mathrm{CJ}$ is in stark contrast with this position since because the CJ considered all crimes enumerated in Article 12(2) of the same character and thus do not require a proportionality test.

Another important issue that emerged in the $B$ and $D$ case is the question of attribution of individual responsibility to persons based on their membership to a terrorist organization. ${ }^{46}$ In $B$ and $D$, the Court first took into consideration the terrorist character of the organization. It then went on to analyze the effect of membership to that organization on the exclusion from protection. The Court concluded that mere membership does not mean automatic exclusion from protection. ${ }^{47}$ Nor does participation in the activities of the organization-pursuant to Article $2(2)(\mathrm{b})$ of Framework Decision 2002/475-automatically mean exclusion. ${ }^{48}$ What is needed is "to attribute to the person concerned a share of responsibility for the acts committed by the organization in question while that person was a member." 49

In the Lounani judgment, the CJEU further elaborated on these issues. Mr. Lounani was convicted by the court in Belgium for participation in terrorist group activities by providing logistical support to a terrorist group by the provision of, inter alia, material resources or information, forgery of passports, fraudulent transfer of passports, and active participation in the organization of a network to send volunteers to Iraq. He was convicted under Article 140 of the amended Belgian Criminal Code, which represents the transposition of Article 2 of Framework Decision 2002/475 into national law. Therefore, Mr. Lounani was found guilty for participation in the activities of terrorist group, but not for the commission of terrorist acts. The Court needed to answer whether his conduct represented a basis for exclusion from refugee status in accordance with Article 12(2)(c). The CJEU noted that Article 12(2)(c) covers acts besides terrorist acts, including, inter alia, acts that Mr. Lounani was found guilty of. ${ }^{50}$ Also, according to the finding in $B$ and $D$, mere membership in a terrorist organization is not enough to trigger the application of Article 12. Therefore, the CJEU-referencing its case law-reiterated that the competent authority must undertake an individual assessment of the specific facts. ${ }^{51}$ The CJ emphasized that in this

\footnotetext{
${ }^{43} I d$. at para. 109.

${ }^{44}$ UNHCR Guidelines on International Protection, supra note 37, at para. 24; UNHCR Statement on Article 1F, supra note 40 , at $10-11$.

${ }^{45}$ UNHCR Guidelines on International Protection, supra note 37, at para. 24.

${ }^{46}$ See Sandesh Sivakumaran, Exclusion from Refugee Status: The Purposes and Principles of the United Nations and Article $1 F(c)$ of the Refugee Convention, 26 INT'l J. of REFUGEE L. 350, 356-61 (2014) (featuring a more in-depth analysis of this issue).

${ }^{47} B$ and $D$, Cases C-57/09 and C-101/09 at para. 88.

${ }^{48}$ Id. at paras. 92,93 .

${ }^{49} \mathrm{Id}$. at para. 95 .

${ }^{50} \mathrm{Id}$. at paras. $45-47$.

${ }^{51}$ Lounani, Case C573/14 at para. 72 .
} 
assessment, the fact that the person concerned is convicted of participation in the activities of a terrorist group, and the finding that a person was a member of leadership of that group, are of particular importance. This defers to the findings in $B$ and $D$, where the CJEU held that a prominent position in terrorist organization is a rebuttable presumption of the person's individual responsibility for the acts committed by that organization. ${ }^{52}$ This is due to the fact that a prominent position in a group is not regarded the same as a leadership of a group-with leadership being a stronger link with the group.

The implications of the Lounani judgment for the interpretation of Article 12 are twofold. First, Lounani adds up the acts that are considered contrary to purposes and principles of the UN. Apart from terrorist acts that were explicitly mentioned in $B$ and $D$, other related acts include the recruitment, organization, transportation, and equipment of individuals traveling to an alien State for the purpose of perpetrating, planning, or preparing a terrorist act. ${ }^{53}$ Therefore, these acts are in and of themselves contrary to the purposes and principles of the UN; it is not needed to show that these persons have ultimately committed terrorist acts. ${ }^{54}$ It is also not needed to show that the person at issue committed terrorist acts. The abovementioned acts are sufficient to establish the individual's responsibility. Second, the Lounani judgment introduces new factors that should be taken into account when deciding an individual's responsibility: Prior convictions for relevant acts; and leadership in the organization.

Another interesting issue that emerged in this case can be found in the Opinion of Advocate General. Namely the United Kingdom claimed that the ruling in Lounani needed to be in conformity with the Shepherd case, ${ }^{55}$ in which the Court interpreted Article 9(2)(e) of the Qualification Directive. This case was referred to the CJ by the German Court, and it dealt with a United States citizen that applied for asylum in Germany after refusing to perform military service in Iraq. He claimed that because of his conduct, he was at risk for criminal prosecution and social ostracism in his country. Because Article 9(2)(e) of the QD contains a provision stating that acts of persecution include "prosecution or punishment for refusal to perform military service in a conflict, where performing military service would include crimes or acts falling under the exclusion clauses set out in Article 12 (2)," the Bavarian Administrative Court asked the Court of Justice to, inter alia, interpret this provision.

The findings of the Court are relevant to the interpretation of Article 12(2)(a) to some extent. It must be kept in mind that the Article 9(2)(e) and Article 12(2)(a) are mutually exclusive. If the applicant already committed crimes under Article 12(2)(a), he would be excluded from the refugee status - therefore, Article 9(2)(e) could not be applied. Article 9(2)(e), in fact, asks for an ex ante assessment of future acts, while Article 12(2)(a) entails an ex post assessment of acts that have already happened. ${ }^{56}$ This is an important finding, as it indicates that the standards of proof for whether excludable acts are committed - such as war crimes, crimes against humanity and crimes against peace-will be deferential in these two situations. In her opinion in the Shepherd case, Advocate General Sharpston explicitly excluded the application of international criminal law standards to the assessment of the fulfillment of conditions for refugee status. ${ }^{57}$ It also seems that by adopting the "sufficiently direct and reasonably plausible" test for participation in war

\footnotetext{
${ }^{52} B$ and $D$, Cases C-57/09 and C-101/09 at para. 98.

${ }^{53}$ Lounani, Case C573/14 at para. 68.

${ }^{54} I d$. at para. 77 .

${ }^{55}$ Case C472/13, Shepherd v. Bundesrepublik Deutschland (Feb. 26, 2015), http://curia.europa.eu/juris/liste.jsf? language $=$ en \&jur $=\mathrm{C}, \mathrm{T}, \mathrm{F} \&$ num $=\mathrm{c}-472 / 13$.

${ }^{56}$ Opinion of Advocate General Sharpston at para. 36, Case C472/13, Shepherd v. Bundesrepublik Deutschland (Nov. 11, 2014), http://curia.europa.eu/juris/document/document.jsf?text=\&docid=159445\&pageIndex=0\&doclang=EN\&mode=lst\&dir= \&occ $=$ first \&part $=1 \&$ cid $=2950180$.

${ }^{57} I d$. at para. 66.
} 
crimes ${ }^{58}$ the CJEU also excluded the international criminal law standard. This reasoning is logical in under the circumstances of this case for two reasons. First, this is a question of whether to give protection to a person. Second, the behavior of this person needs to be assessed based on a situation that did not happen, and on the fact that the person tried to escape. In such circumstances, the standard of proof needs to be set on a lower scale. The question remains, however: What is the standard of proof in circumstances of refugee status exclusion, where the question concerns the exclusion from protection and the act was already committed? It seems logical that the standard of proof should be set on a higher scale. It is still not certain, however, whether that standard of proof will be identical to the standards proscribed by international criminal law. In the Lounani case, AG Sharpston concluded that the test developed in the Shepherd case is not of assistance for the resolution of the case at hand, thereby rejecting the standard set therein. ${ }^{59}$ Because the exclusion provision in EU law is taken from Article 1(F) of the Refugee Convention, the practice of the UNHCR and the national courts implementing this provision can be of help. According to the UNHCR, "[i]n order to satisfy the standard of proof under Article 1F, clear and credible evidence is required. It is not necessary for an applicant to have been convicted of the criminal offence, nor does the criminal standard of proof need to be met." ${ }^{\prime \prime}$ The UNHCR also notes that "the standard of proof should be high enough to ensure that bona fide refugees are not excluded erroneously. Hence, the 'balance of probabilities' is too low a threshold." 61 Therefore, the UNHCR's acceptable standard of proof lies somewhere between the criminal standard and the balance of probabilities. Other authors, however, have different stances. They claim that the standard of proof in the cases of refugee status exclusion is "less than both the criminal standard (beyond reasonable doubt) and the civil standard (balance of probabilities)." ${ }^{2}$ Some useful guidance can be found in the UK Supreme Court judgment in Al-Sirri case, where the Court stated that it strived to "discern the autonomous meaning of the words "serious reasons for considering." 63

Having all that in mind, we can conclude that the CJEU sought to elaborate its caselaw in the field of refugee status exclusion, and that it had done so while protecting the autonomous EU legal order-which sometimes results in the departure from practices of other national courts. Nonetheless, the most interesting case in this field has yet to be handled by the Court, in which it will put an end to the debate about the potential fourth basis for refugee status exclusion under EU law. Until that judgment arrives, it is important to point out the possible changes to EU legislation, as they can shed light on this topic.

\section{E. Commission Proposal 3.2.--Bases for Exclusion in Proposed Qualification Regulation}

The third phase of the Common European Asylum System's establishment started with the proposed reform of EU legislation in this field. The first set of proposals included reform of

\footnotetext{
${ }^{58}$ Shepherd, Case C472/13 at para. 38.

${ }^{59}$ Opinion of Advocate General Sharpston at paras. 81-82, Case C573/14, Commissaire Général aux Réfugiés et aux Apatrides v. Lounani (May 31, 2016), http://curia.europa.eu/juris/document/document.jsf?text=\&docid=179041\&page Index $=0 \&$ doclang=en\&mode $=1$ st $\&$ dir $=\&$ occ $=$ first $\&$ part $=1 \& \mathrm{cid}=2951730$.

${ }^{60} \mathrm{UNHCR}$ Guidelines on International Protection, supra note 37, at para. 35.

${ }^{61}$ U.N. High Comm'r for Refugees, Background Note on the Application of the Exclusion Clauses: Article 1F of the 1951 Convention Relating to the Status of Refugees, para. 107 (Sept. 4, 2003), https://www.refworld.org/docid/ 3 f5857d24.html.

${ }^{62}$ See European Asylum Support Office, Exclusion: Articles 12 And 17 Qualification Directive (2011/95/Eu), A Judicial Analysis, at 41 (Jan. 2016) (citing Jean-Yves Carlier \& Pierre d'Huart, L'Exclusion du Statut de Réfugié: Cadre General, in Asile et Extradition: Théorie et Pratique de L'Exclusion du Statut de Réfugié 3, 7-9 (Vincent Chetail \& Caroline Laly-Chevalier eds., 2014), https://www.easo.europa.eu/sites/default/files/public/Exclusion\%20Final\% 20Print\%20Version.pdf; see also GoodWIN-GILL \& MCADAM, supra note 35, at 165.

${ }^{63} \mathrm{Al}-$ Sirri v. Secretary of State for the Home Department [2012] UKSC 54, [75].
} 
the Dublin regulation, ${ }^{64}$ the EURODAC regulation ${ }^{65}$ and the new mandate for the EU Asylum Agency. ${ }^{66}$ The second set included proposals for replacing the Asylum Procedures and Qualification Directives with Regulations and a revision of Reception Conditions Directive. In its proposal for the new Qualification Regulation, the Commission pointed out that there are serious differences in "recognition rates and type of protection status granted by each Member State as well as the content of the protection." ${ }^{67}$ These discrepancies undermine the whole EU asylum system because they lead to situations that the CEAS intended to prevent-secondary movement and forum shopping. Therefore, Commission was of stance that the existing Directive needed to be replaced by a Regulation and that certain provisions needed to be changed in order to correct the shortcomings of the existing Directive. Therefore, in order to further harmonize the common criteria recognizing applicants for international protection, the Commission proposed changes to Article 12(2). In order to introduce systematic and regular status reviews, they also proposed changes to Article 14.

Proposed changes to Article 12(2) incorporate the findings of relevant case law from the CJEU. From these findings, it is suggested to incorporate two additional lines. The first line-which would become Article 12(5) — seeks to further explain the scope of the material application of points (b) and (c) by expressly stating which acts will be regarded as a serious non-political crime. ${ }^{68}$ It includes: a) Particularly cruel actions when the act in question is disproportionate to the alleged political objective; and (b) terrorist acts, which are characterized by their violence towards civilian populations, even if committed with a purportedly political objective. The second line-which would become Article 12 (6) —explains that an assessment of whether a person will be excluded from refugee status shall depend exclusively on whether the conditions set in that Article are met and shall not be subject to any additional proportionality assessment in relation to the particular case. First, it is unusual that the Commission purports to further elaborate on Article $12(2)(\mathrm{c})$ - the provision regarding acts contrary to purposes and principles of the $\mathrm{UN}$ - by explaining the notion of non-political act not mentioned therein. It is questionable why the notion of a serious non-political crime is relevant to the determination of what constitutes acts contrary to purposes and principles of the UN. It is true that in the $B$ and $D$ case, the Court dealt with the interpretation of both (b) and (c) of Article 12 (2), but it still made separate analyses of these two lines.

As stated in the Commission's proposal, the lines 5(b) and 6 clearly reflect the CJEU's findings in the $B$ and $D$ case. $^{69}$ It is less obvious, however, from where line 5(a) stems. The Commission explained that both points (a) and (b) of line 5 were added in order "to clarify that the commitment of certain crimes (particular cruel actions and terrorist acts) are a basis for exclusion from

\footnotetext{
${ }^{64}$ Proposal for a Regulation of the European Parliament and of the Council Establishing the Criteria and Mechanisms for Determining the Member State Responsible for Examining an Application for International Protection Lodged in one of the Member States by a Third-Country National or a Stateless Person (Recast), COM (2016) 270 final (May 4, 2016), https:// eur-lex.europa.eu/legal-content/EN/TXT/PDF/?uri=CELEX:52016PC0270\&from=EN.

${ }^{65}$ Proposal for a Regulation of the European Parliament and of the Council on the Establishment of "Eurodac" for the Comparison of Fingerprints for the Effective Application of [Regulation (EU) No 604/2013 Establishing the Criteria and Mechanisms for Determining the Member State Responsible for Examining an Application for International Protection Lodged in One of the Member States by a Third-Country National or a Stateless Person], for Identifying an Illegally Staying Third-Country National or Stateless Person and on Requests for the Comparison with Eurodac Data by Member States' Law Enforcement Authorities and Europol for Law Enforcement Purposes (Recast), COM(2016) 272 final (May 4, 2016), https://eur-lex.europa.eu/legal-content/EN/TXT/PDF/?uri=CELEX:52016PC0272\&from=EN.

${ }^{66}$ Proposal for a Regulation of the European Parliament and of the Council on the European Union Agency for Asylum and Repealing Regulation (EU) No 439/2010, $\operatorname{COM(2016)~} 271$ final (May 4, 2016), https://eur-lex.europa.eu/resource.html? uri=cellar:ce773c1e-1689-11e6-ba9a-01aa75ed71a1.0001.02/DOC_1\&format=PDF.

${ }^{67}$ Proposal for Qualification Regulation, supra note 5, at 7.

${ }^{68} \mathrm{Id}$. at 37.

${ }^{69}$ See $B$ and D, Cases C-57/09 and C-101/09 at para. 81 (regarding terrorist acts); id. at paras. 106-11 (regarding proportionality).
} 
being a refugee even if committed with a political objective." ${ }^{70}$ Particularly cruel actions, however, were already included as a basis for exclusion in the wording of Article 12(2)(b). What the proposed line is, in fact, seeking to explain is that the cruelty of action is to be measured based on its proportionality to the alleged political objective. Namely, an action is cruel if it is disproportionate to the alleged political objective.

As for the question of proportionality-while it is obviously in line with CJEU case law-this line of reasoning is not in accordance with the UNHCR's stance. May be this difference in opinions was the reason the legislature was particularly eager to codify the Court's position.

The changes proposed in Article 14 are highly problematic. Even though line 5 still uses the non-obligatory wording "may decide not to grant status to refugee," the bases for this decision are expanded. Now, they include the situation where "misrepresentation or omission of facts, including the use of false documents, was decisive for the granting of refugee status," as well as the situation defined in Article 23(2). ${ }^{71}$ Article 23(2) of the draft Qualification Regulation contains an exception to the non-refoulement principle. Also, in Article 23(2), a line was added that provides an obligation for states to withdraw refugee status in accordance with Article 14 in cases where a non-refoulement exception situation occurs. This means that the relationship between exclusion from refugee status and exceptions to the non-refoulement principle is formalized and made explicit.

This is problematic on two grounds. First, a direct link is created between two legal solutions that pertain to different situations and have completely different legal backgrounds and consequences as already explained. Second, the fact that refugee status shall be withdrawn based on an exception to the non-refoulement principle is in stark contrast with the prevailing understanding of this principle. Based on the current legislation in force, an exception to non-refoulement could potentially become a basis for not giving refugee status when the status is still not conferred. If the refugee gained the refugee status, however, it was only possible to refoul him-under Article 21 (2) — and deny him a residence permit — under Article 21 (3) — but not possible to take away his/her refugee status. Also, this provision was termed in non-binding way using the notion may. Now, according to the proposal for Qualification Regulation, Article 23 states in mandatory terms that the refugee status shall be withdrawn. ${ }^{72}$

\section{F. Conclusion}

In EU law, the bases for exclusion from refugee status are founded on the premise that a person is not deserving of protection and are derived from international law provisions. Nonetheless, through changes in the legislation and jurisprudence of Court of Justice of the European Union, these norms slowly began to gain a new meaning-detached from their original source. While the EU legislature in 2004 practically copied bases for exclusion from the Refugee Convention, it nevertheless included a provision that left the door open for additional basis for exclusion.

The legal framework of exclusion from refugee status is also influenced by the case law of the CJEU. While the solutions are usually helpful and in line with international legal standards-e.g., inclusion of terrorist acts in non-political acts-few issues in the CJEU are dealt with differently than its national counterparts - e.g., the question of proportionality. Also, in the legislation itself, the exception to non-refoulement was included as a possible reason for not granting status to refugee, or revoking it. While some authors and the UNHCR expressed their concerns about this mélange, this question remained unsettled and is somehow dormant until today. There is a pending case before the Court of Justice of the EU that will hopefully provide us with the long-awaited

\footnotetext{
${ }^{70}$ Proposal for Qualification Regulation, supra note 5, at 13.

${ }^{71} I$. at 38 .

${ }^{72} I d$. at 44 .
} 
response and put an end to this academic debate. Nonetheless, the hopes that this debate will become obsolete after this verdict are dashed by the new Commission's proposal for the Qualification Regulation. In this proposal, the relation between the exclusion from refugee status and the exception to non-refoulement is made more explicit and unambiguous. Even though this proposal can and probably will suffer some changes, it remains to be seen how this topic will be tackled. Until then, the question remains - to exclude or not to exclude. 